\title{
Illegal trade of morphologically distinct populations prior to taxonomic assessment and elevation, with recommendations for future prevention
}

Matthijs P. van den Burg and Bruce J. Weissgold

5

Matthijs P. van den Burg (Corresponding author). Department of Biogeography and Global Change,

Museo Nacional de Ciencias Naturales, Spanish National Research Council (CSIC), c/ José

Gutiérrez Abascal 2, 28006 Madrid, Spain. E-mail thijs.burg@gmail.com. orcid.org/0000-0001-

8276-0713

10 Bruce J. Weissgold. Independent Consultant, Fairfax, Virginia, United States. 


\section{Abstract}

30 The negative impacts of international wildlife trafficking are well known, and such negative impacts can be even more pronounced for insular species. This dynamic market needs close monitoring, and when novel species appear in the commercial trade relevant authorities should be able to react in order to reduce negative impacts on wild populations. Here we describe a novel case where an insular endemic form of the Iguana iguana complex has entered the international commercial trade, likely

35 stimulated by efforts to elevate the form taxonomically. Despite the absence of authorized export permits from the relevant CITES authority, we identify animals that are sold in a range of countries and the likely pathway and methods of importation. We provide recommendations to prevent future illegal collection and trafficking that could be implemented for other taxa. We call for increased awareness of the higher economic value of taxa considered for future taxonomic elevation, and increased monitoring of the commercial trade in order to act promptly when illegal activity is detected.

\section{Keywords}

CITES legislation; Commercial trade; Iguana iguana; Illegal trade; Laundering; Pet trade

\section{Main text}

In the current digital era, ongoing efforts to understand and describe Earth's biodiversity are greatly aided by the increased public availability of scientific information. These efforts are of great interest to researchers and students, policy makers, conservationists, and the general public. However, the

50 entry of certain information into the public sphere can have negative consequences (Stuart, Rhodin, Grismer, \& Hansel, 2006; Meijaard, \& Nijman, 2014; Lindenmayer, \& Scheele, 2017). A major concern is that species descriptions or taxonomic elevations cause wildlife trafficking through increased desirability within the international trade.

One major threat to a variety of species is the global trade in wildlife. Insufficiently regulated

55 and controlled collection and trade can result in unsustainable harvest and subsequent population declines; this is also true for herpetofauna species (Roa, Duckworth, Roberts, \& Shepherd, 2014; Auliya, Ariano-Sanchez, Baard, \& Brown, 2016; Rowley, Shepherd, Stuart, Nguyen, \& Hoang, 2016). As scientists seek to better understand our planet's biodiversity, novel data can also be used for financial gain through illegal trade, including financial investment speculation in live animals, a 
60 newly emergent threat in the commercial reptile trade (Brian Horne, pers. comm). The occurrence of recently (re)discovered reptile species within the pet trade has occurred multiple times (see Auliya et al. [2016] and Rowley et al. [2016]), even when researchers refrained from publishing locality data. For example, the recently described Echinotriton maxiquadratus (Mountain spiny crocodile newt) appeared in the pet trade despite the fact that the authors excluded locality data from their original publication and asked others to refrain from sharing the data (Rowley et al., 2016; IUCN \& TRAFFIC, 2019). However, specifically stating that locations should not be shared might unintentionally spark interest in the lucrative international trade. Furthermore, it is not unusual for commercial traders to attempt to legalize otherwise illegally collected wild specimens by fraudulently obtaining CITES permits indicating that the animals were bred in captivity (Nijman, \& Shepherd, 2009; Janssen, \& Chng, 2018). Commercial hobbyists and dealers may be issued CITES (Convention on International Trade in Endangered Species of Wild Fauna and Flora) export permits for the offspring of illegally collected and/or trade animals, therefore, creating a perverse incentive for trafficking. This problem was recently discussed and debated at the $18^{\text {th }}$ meeting of the CITES Conference of the Parties, resulting in an important interpretive statement on the implementation of CITES - Resolution Conf.

75 18.7, Legal acquisition findings (https://cites.org/sites/default/files/document/E-Res-18-07.pdf). Lastly, although commercial trade in recently described species is common, instances where a proposed taxonomic revision spurs a surge in illegal collection and international trade are rare. This paper summarizes the presence in international commercial trade of specimens of a phenotypic distinct insular population of Iguana iguana prior to taxonomic reassessment.

Species of Iguaninae (ITWG, 2016) are long-lived, generally large, herbivorous lizards that occur in the Americas, West Indies and several pacific islands. Globally, Iguaninae are considered among the most endangered lizard groups as $>80 \%$ of species are considered as threatened (IUCN, 2020), and many species have limited ranges, being insular endemics to one or a small number of islands (ITWG, 2016). Correspondingly, numerous species are listed on Appendix I and II of CITES.

85 As with many other taxa (Hedges et al., 1992), iguanids show a long evolutionary history (Malone, Wheeler, Taylor, \& Davis, 2000; ITWG, 2016) and are under current pressure, threatened by a wide range of problems; e.g. invasive species, habitat destruction, hybridization and the impacts of tourism and other anthropogenic activities (Iverson, Grant, Knapp, \& Pasachnik, 2016; Pasachnik, Carreras De Leon, \& Léon, 2016; van den Burg, Madden, van Wagensveld, \& Buma, 2018a; van den Burg, 90 Brisbane, \& Knapp, 2020).

Iguana iguana, listed as a CITES Appendix II species since 1977 and commonly traded pet (Fig. 1), occurs throughout most of Central- and South America, including a number of Caribbean 
islands (Bock, Malone, Knapp, Aparicio, \& Avila-Pires, 2019). Despite this species' wide native distribution and identified phenotypic and genetic differences (Lazell, 1973; Malone, \& Davis, 2004), extensive phylogeographic and phenotypic diversity research only recently commenced (Breuil, 2013; Stephen, Reynoso, Collett, \& Hasbun, 2013; Breuil et al., 2019). However, a thorough study on range-wide phenotypic variation is still lacking. Besides native populations, numerous established alien populations are known, having originated primarily in the pet-trade (Falcón, Ackerman, \& Daehler, 2012; van den Burg, van Belleghem, \& De Jesús Villanueva, 2020). In fact, the pet trade

100 has been identified as a threat to local mainland populations due to the unsustainable harvest of wild animals (Stephen, Pasachnik, Reuter, Mosig \& Ruyle, 2011), and despite an allowable and robust legal trade under CITES, trafficking of the species has been recorded from several countries in Central America Caribbean islands (Stephen et al., 2011; Noseworthy, 2017; Breuil et al., 2019).

Based on a morphological assessment of several island localities and mainland I. iguana

105 lineages, Breuil (2013) suggested the presence of cryptic diversity and the presence of new taxonomic units for the populations on St. Lucia, Saba and Montserrat. Hereafter, Breuil, Vuillaume, Schikorski, Krauss, \& Morton (2019) furthered this view: "Breuil et al. (in preparation) work on the genetic and morphological originality of the insular population of Saba and Montserrat". Additionally, information regarding the intention to taxonomically elevate the Saba population comes from a 2011

110 social-media post from the Saba Conservation Organization that mentioned: “.... a study is [under]way to scientifically establish the Saba Black Iguana as a distinct subspecies of the Green Iguana (Iguana iguana), only found on Saba". This information was shared widely and can be found on numerous websites and social media groups. Overall, information concerning the potential uniqueness and future scientific recognition of the melanistic I. iguana populations of Saba, and Montserrat, has been

115 publicly available for seven years; and was recently elevated to species level, Iguana melanoderma (Breuil, et al. 2020). Here we focus on the trade of these melanistic Iguana localities (Saba and Montserrat) and identify countries were such animals are sold, and the pathway and methods of importation and trade; data collation and manuscript preparation were completed before publication of Breuil et al. (2020). We collated information from the CITES Trade Database 120 [https://trade.cites.org/], through on-line reviews of advertisements and social-media posts about melanistic iguanas and contact with commercial hobbyists, dealers and private keepers.

No I. iguana exports from Saba are reported in the CITES Trade Database through the end of 2019 (CITES, 2020). However, based on data collected in 2016 (Noseworthy, 2017) and our review of online advertisements and social-media posts, animals advertised as "Black dragons," "Saba black 125 iguanas," "Saba Island iguanas" with phenotypic characteristics of the melanistic populations are 
currently in private collections and/or sold in the United States, Germany, Indonesia, Belgium, Malaysia and Japan. We found that at least 12 companies/collectors have acquired iguanas indicated as being from Saba since 2015, with recorded posts and adverts for every year. Furthermore, although to collection of detailed information on wildlife trade routes and business practices can be difficult, we gained insights about the origin and trade pathways from retailers and private owners of melanistic iguanas. Namely, one U.S.A. retailer states online about their melanistic Saba iguanas: "They are captive bred on a different island and imported"; including one image with info keywords "SXM" (Sint Maarten) and "Anguilla". In addition, one commercial buyer described how melanistic animals from St. Maarten have been imported into Europe as captive-bred animals under CITES permits 135 approved by the local authority. Lastly, another commercial buyer indicated that Saba iguanas are imported into the United States from Barbabos. Overall, despite the absence of CITES export records from Saba (CITES, 2020), all sellers claim to have appropriate CITES documentation accompanied with their stock animals.

Claims of captive breeding have been fraudulently used to trade illegally caught wild animals

140 (Jansen, \& Chng, 2018). We tracked official documentation (CITES, 2020) after receiving information about pathways and origins of melanistic iguanas in the trade (see above). We found that captive-bred I. iguana have been exported from Sint Maarten and Barbados (CITES, 2020), islands without unique species localities but instead alien I. iguana populations (Censky, Hodge, \& Dudley, 1998; van den Burg, Meirmans, van Wagensveld, Kluskens, \& Madden, 2018b). Namely, since 2014,

145 a total of 807 live iguanas have been exported from Sint Maarten $(n=381)$ and Barbados $(n=426)$, to Canada, Czech Republic, Germany, Hong Kong, Japan, United States and Thailand. Information requested from these CITES registered permits in June 2019 had not been provided by both the Sint Maarten and Barbados authorities at the time of acceptance of this manuscript, despite previous contact between the authors and the St. Maarten authority. As trade in the CITES Trade Database is

150 reported as I. iguana, we cannot be certain that all these captive-bred exports are of Saba iguanas, or of the local invasive populations. However, we only found one retailer selling St. Maarten iguanas, and none for Barbados iguanas. Given multiple lines of evidence we argue that illegal trade in iguanas from Saba is facilitated through either false claims of captive breeding, and/or successful breeding of trafficked founder stock on Sint Maarten and Barbados; close regional proximity of St. Maarten and

155 Barbados to Saba and Montserrat, the absence of native I. iguana populations on St. Maarten and Barbados, only a single retailer appears to sell iguanas from St. Maarten, and based on information about origin and transport pathway from purchasers of melanistic iguanas. We argue that this illegal trade is facilitated through the issuance of CITES export permits by the relevant authorities. 
Here we report the illegal international trade of a species locality prior to taxonomic

160 assessment and elevation for the high-end commercial hobbyist pet market. As no exports have been reported by the relevant CITES authorities, we provide recommendations to combat trafficking and better ensure that CITES permits are not issued for the onward trade of smuggled animals and/or their offspring. We recommend that Management Authorities of distinct insular Iguana lineages (Saba, Montserrat, St. Lucia, St. Vincent and Grenadines) publish zero annual export quotas to communicate

165 that the commercial export of their populations are not permitted. To ensure that governance or corruption issues are not impacting the regulation and enforcement of applicable laws and regulations, the CITES Secretariat should work with the relevant authorities of St. Maarten to determine why their 2015-2018 I. iguana exports were not reported. This will better ensure all trade is legal and properly documented. With ongoing efforts to understand Iguana phylogeography, additional divergent phenotypes will likely be discovered. Hence, we recommend that the CITES Animals Committee consider a revision of the I. iguana Standard Taxonomic Reference to ensure that it reflects currently accepted taxonomy. For CITES-listed species, relevant Management Authorities should only permit export if they are satisfied the specimens and their founder stock were not obtained illegally; the guidance of CITES Resolution Conf. 18.7, Legal acquisition findings can be instructive in these

175 efforts. Especially in phenotypic diverse taxa an identification guide could help efforts to counter smuggling (Stephen, \& Binns, 2011) and help exporting and importing Management Authorities to prevent fraudulent trade practices. Additionally, a genetic reference database for variable loci can aid the identification of the origin of ceased individuals, although we note the current logistical, cost and related difficulties in applying such forensic techniques to combat wildlife trafficking. With shifting taxonomy and descriptions of new species, these recommendations are not isolated to the present case and can help prevent illegal trade in current and novel species, including unique localities.

In the situation presented here, as well as in others where the fraudulent use of CITES permitting system is suspected, both exporting and importing countries can take action. Namely, exporting Parties (St. Maarten and Barbados) should review their export permit issuance processes to ensure that permits are not issued for trafficked animals or their offspring. Additionally, importing Parties should pay close attention to imports of Iguana sp. of these and other Caribbean islands to better ensure that illegal trade is detected. Importing Parties should scrutinize export permits and contact the relevant authorities (Saba, St. Maarten and Barbados) to verify the authenticity of permits and to ensure that those were issued in compliance with actual CITES standards. When fraudulent 190 use of the CITES permitting system is detected or suspected, the relevant authority (here Saba) should make other CITES Parties aware to better detect irregularities and take actions. One method is to 
request the CITES Secretariat to issue a Notification to the Parties indicating that no lawful export (of Iguana melanoderma) has been authorized, and therefore no Management Authorities should issue (re-) export permits or permits for offspring from such illicit founder stock. This step will strengthen the implementation of CITES Resolution Conf. 18.7, Legal acquisition findings; an important interpretive statement designed to combat this very type of illegal international wildlife trade. Above methods can help prevent negative conservation impacts of illegal wildlife trade and safeguard the integrity of the CITES permitting system, which is intended to prevent the unsustainable exploitation of wild species. Finally, we urge zoos and commercial hobbyists to carefully examine

200 the origins of specimens and their founder stock - before adding new animals to their collections - to better ensure that they were not illegally acquired.

The majority of the $\sim 7.8$ million animal species yet-to-be described on Earth will likely be small ranged and rare (Mora, Tittensor, Adl, Simpson, \& Worm, 2011), and potentially of great interest to the commercial hobbyist and pet trade, especially those with unique phenotypic characteristics. Researchers should strengthen their awareness of the potential negative consequences associated with publication of sensitive information not only for new or rediscovered taxa but also for those under consideration of taxonomic elevation. Expert advice in cases where future illegal activity can be expected can be sought from the wider wildlife trade community. Prior to publication of sensitive information, researchers should ensure the relevant CITES and enforcement authorities

210 are informed so they are able to monitor for trafficking and can take relevant steps to prevent negative conservation impacts. Globally, it will be important to closely monitor the commercial hobbyist and pet trade and rapidly react to newly traded species in order to prevent overexploitation, extirpation or even extinction.

215 Acknowledgements We thank Catherine Malone and Willow Outhwaite for improving an older version of this manuscript. This research received no specific grant from any funding agency, or commercial or not-for-profit sectors.

\section{References}

220 Auliya, M., Altherr, S., Ariano-Sanchez, D., Baard, E. H., \& Brown, C. et al. (2016). Trade in live reptiles, its impact on wild populations, and the role of the European market. Biological Conservation, 204, 103-119. https://doi.org/10.1016/j.biocon.2016.05.017.

Bock, B., Malone, C. L., Knapp, C., Aparicio, J., \& Avila-Pires, T. C. S. et al. (2018). Iguana iguana. The IUCN Red List of Threatened Species 2018: 
bioRxiv preprint doi: https://doi org/10.1101/2020.05.26.116426; this version posted June 4,2020 . The copyright holder for this preprint (which was not certified by peer review) is the author/funder, who has granted bioRxiv a license to display the preprint in perpetuity. It is made available under aCC-BY-NC-ND 4.0 International license.

e.T174481A1414646. http://dx.doi.org/10.2305/IUCN.UK.2018-

1.RLTS.T174481A1414646.en. [accessed 14 June 2019].

Breuil, M. (2013). Caractérisation morphologique de l'iguane commun Iguana iguana (Linnaeus, 1758), de l'iguane des Petites Antilles Iguana delicatissima Laurenti, 1768 et de leurs hybrides. Bulletin de la Société Herpétologie de France, 147, 309-346.

Breuil, M., Vuillaume, B., Schikorski, D., Krauss, U., Morton, M. N. et al. (2019). A story of nasal horns: two new subspecies of Iguana Laurenti, 1768 (Squamata, Iguanidae) in Saint Lucia, St Vincent \& the Grenadines, and Grenada (southern Lesser Antilles). Zootaxa, 4608, 201232.

235 http://dx.doi.org/10.11646/zootaxa.4608.2.1.

Breuil, M., Schikorski, D., Vuillaume, B., Krauss, U., Morton, M. N. et al. (2020). Painted black: Iguana melanoderma (Reptilia, Squamata, Iguanidae) a new melanistic endemic species from Saba and Montserrat islands (Lesser Antilles). ZooKeys, 926, 95-131. https://doi.org/10.3897/zookeys.926.48679.

240 Censky, E. J., Hodge, K., \& Dudley, J. (1998). Over-water disperdal of lizards due to hurricanes. Nature, 395, 556. https://doi.org/10.1038/26886.

CITES (2019). CITES trade statistics derived from the CITES Trade Database, UNEP World Conservation Monitoring Centre, Cambridge, UK.

245 Hedges, S. B., Hass, C. A., \& Maxson, L. R. (1992). Caribbean biogeogprahy: molecular evidence for dispersal in West Indian terrestrial vertebrates. Proceedings of the National Academy of Sciences, 89, 1909-1913. https://doi.org/10.1073/pnas.89.5.1909.

IUCN (2019). The IUCN Red List of Threatened Species. Version 2019-1.

250 http://www.iucnredlist.org. [accessed 14 June 2019].

IUCN \& TRAFFIC (2019). IUCN/TRAFFIC Analyses of the Proposals to Amend the CITES Appendices. Prepared by IUCN Global Species Programme and TRAFFIC for the Eighteenth Meeting of the Conference of the Parties to CITES. IUCN - International Union for Conservation of Nature, Gland, Switzerland.

255 Iverson, J. B., Grant, T. D., Knapp, C. R., \& Pasachnik, S. A. (Eds.). (2016). Iguanas: Biology, Systematics, and Conservation. Herpetological Conservation and Biology 11 (Monograph $6)$.

IWTG. (2016). A checklist of the iguanas of the world (Iguanidae; Iguaninae). In: Iverson, J. B., Grant, T. D., Knapp, C. R. \& Pasachnik, S. A. (eds), Iguanas: Biology, Systematics, and Conservation. Herpetological Conservation and Biology, pp. 4-46.University of California Press, US.

Jansen, J., \& Chng, S. C. L. (2018). Biological parameters used in setting captive-breeding quotas for Indonesia's breeding facilities. Conservation Biology, 32, 18-25. https://doi.org/10.1111/cobi.12978.

265 Lazell, J. D. (1973) The Lizard Genus Iguana in the Lesser Antilles. Bulletin of the Museum of Comparative Zoology, 145, 1-28.

Lindenmayer, D., \& Scheele, B. (2017). Do not publish. Science, 356, 800-801. https://doi.org/10.1126/science.aan1362.

Malone, C. L., Wheeler, T., Taylor, J. F., \& Davis, S. K. (2000). Phylogeography of the Caribbean Rock Iguana (Cyclura): Implications for Conservation and Insights on the Biogeographic History of the West Indies. Molecular Phylogenetics and Evolution, 17, 269-279. https://doi.org/10.1006/mpev.2000.0836.

Malone, C. L., \& Davis, S. K. (2004). Genetic contributions to Caribbean iguana conservation. In: Alberts, A. C., Carter, R. L., Hayes, W. K. \& Martins, E. P. (eds), Iguanas: Biology and Conservation, pp. 45-57. University of California Press, US. 
bioRxiv preprint doi: https://doi org/101101/2020.05.26.116426; this version posted June 4,2020 . The copyright holder for this preprint (which was not certified by peer review) is the author/funder, who has granted bioRxiv a license to display the preprint in perpetuity. It is made available under aCC-BY-NC-ND 4.0 International license.

Meijaard, E. \& Nijman, V. (2014). Secrecy considerations for conserving Lazarus species.

Biological Conservation, 175, 21-24. https://doi.org/10.1016/j.biocon.2014.03.021.

Mora, C., Tittensor, D. P., Adl, S., Simpson, A. G. B., \& Worm, N. (2011). How many species are there on Earth and in the ocean? PLoS Biology, 9, e1001127. https://doi.org/10.1371/journal.pbio.1001127.

Nijman, V., \& Shepherd, C. R. (2009). Wildlife trade from ASEAN to the EU: issues with the trade in captive-bred reptiles from Indonesia. TRAFFIC Europe, Brussels

Noseworthy, J. (2017). Cold-blooded conflict: tackling the illegal trade in endemic Caribbean island reptiles. Unpublished M.Sc. thesis, University of Cambridge, Cambridge, pp. 1-106.

Pasachnik, S. A., Carreras De Leon, R., \& Léon, Y. M. (2016). Protected only on paper? Three case studies from the Dominican Republic. Caribbean Naturalist, 30, 1-19.

Roa, M., Duckworth, J. W., Roberts, R., \& Shepherd, C. R. (2014). Averting the imminent extinction of South-East Asian vertebrate species: Asian Species Action Partnership. TRAFFIC Bulletin, 26, 15-17.

Stephen, C. L., \& Binns, J. (2011). Ctenosaura identification guide. Available online; http://www.iucn-isg.org/wp-content/uploads/2014/08/Cteno ID GuideLowRez_15Aug2011.pdf

Stephen, C. L., Pasachnik, S., Reuter, A., Mosig, P. \& Ruyle, L. et al. (2011). Survey of Status, Trade, and Exploitation of Central American Iguanas. Iguanas Specialist GroupInternational Iguana Foundation. TRAFFIC- USFWS-UVU.

Stephen, C. L., Reynoso, V. H., Collett, W. S., \& Hasbun, C. R. et al. (2013). Geographical structure and cryptic lineages within common Green Iguanas, Iguana iguana. Journal of Biogeography, 40, 50-62.

$300 \quad$ https://doi.org/10.1111/j.1365-2699.2012.02780.x.

Stuart, B. L., Rhodin, A. G., Grismer, L. L., \& Hansel, T. (2006). Scientific description can imperil species. Science, 312, 1137. https://doi.org/10.1126/science.312.5777.1137b.

van den Burg, M. P., Madden, H., van Wagensveld, T. P., \& Buma, C. (2018a). Anthropogenic Mortality in the Critically Endangered Lesser Antillean Iguana (Iguana delicatissima) on St. Eustatius. IRCF Reptiles \& Amphibians, 25, 120-124.

van den Burg, M. P., Meirmans, P. G., van Wagensveld, T. P., Kluskens, B., \& Madden, H. et al. (2018b). The Lesser Antillean iguana (Iguana delicatissima) on St. Eustatius: Genetically depauperate and threatened by ongoing hybridization. Journal of Heredity, 109, 426-437.

310 https://doi.org/10.1093/jhered/esy008.

van den Burg, M. P., Brisbane, J. L. K., \& Knapp, C. R. (2020). Post-hurricane relief facilitates invasion and establishment of two invasive alien vertebrate species in the Commonwealth of Dominica, West Indies. Biological Invasions, 22, 195-203. https://doi.org/10.1007/s10530-019-02107-5.

315 van den Burg, M. P., Van Belleghem, S. M., \& De Jesús Villanueva, C. N. (2020). The march of the Common Green Iguana (Iguana iguana): early establishment in Singapore and Thailand is facilitated by the pet trade and recreational parks. bioXriv doi: https://doi.org/10.1101/2020.02.04.933598.s 
bioRxiv preprint doi: https://doi.org/10.1101/2020.05.26.116426; this version posted June 4, 2020. The copyright holder for this preprint (which was not certified by peer review) is the author/funder, who has granted bioRxiv a license to display the preprint in perpetuity. It is made available under aCC-BY-NC-ND 4.0 International license.

\section{Figures and captions}

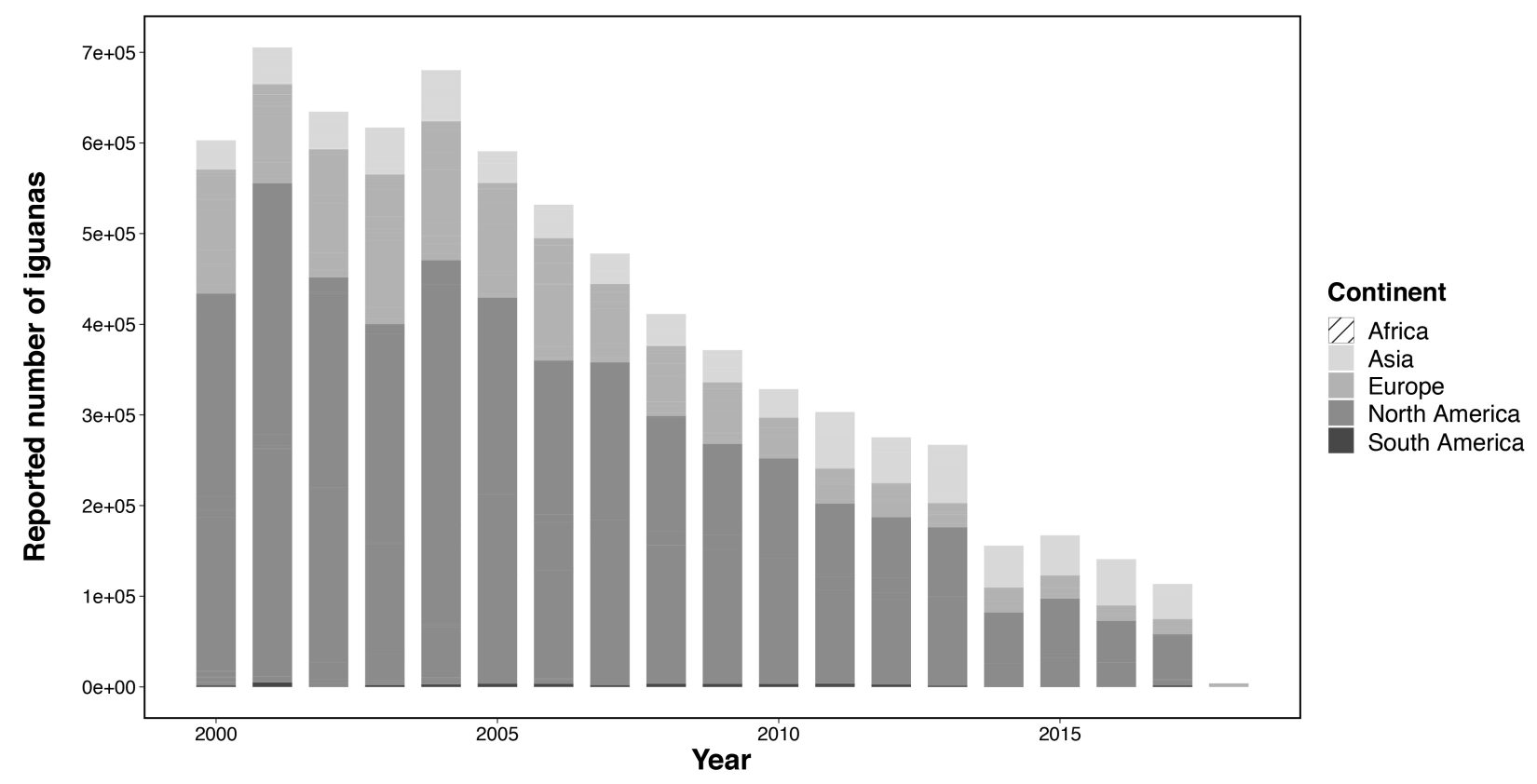

Figure 1 Minimum CITES reported import of Iguana iguana for commercial or personal use between 2000 and 2017. 